\title{
Strategy Research of the Innovating-Style City of Xi'an Low Carbon-Based View-Main Body Innovation
}

\author{
Junfeng Liu \\ Economic \& Management School, Xi'an Shiyou University, Xi'an, China \\ Email: liujunfeng98@xsyu.edu.cn
}

Received 2 April 2015; accepted 17 August 2015; published 20 August 2015

Copyright (C) 2015 by author and Scientific Research Publishing Inc.

This work is licensed under the Creative Commons Attribution International License (CC BY).

http://creativecommons.org/licenses/by/4.0/

(c) () Open Access

\begin{abstract}
Beginning with the conception of the innovating-style city, path selection of the innovating-style city of Xi'an based on low-carbon view is introduced and one of the strategies makes it true-main body innovation, including enterprise innovation strategy, management innovation strategy and talent innovation strategy.
\end{abstract}

\section{Keywords}

The Innovating-Style City, Innovation Strategy, Main Body Innovation, Path Selecting, Low Carbon

\section{Introduction}

The city is an important carrier of the economic and social development; the ranking of the country's comprehensive national strength is largely dependent on the city’s overall competitiveness ranking. More than $70 \%$ of China GDP sources, about $80 \%$ of tax from the city, more than $90 \%$ of universities and scientific research efforts are concentrated in the cities; the city can be imagined for the promotion of national economic development significance. With the rapid and sustained development of economic and social, urban development, resource constraints are more and more becoming prominent contradictions of the people and the environment, relying on the land, resources, capital and other traditional factors of production which can no longer meet the needs of the urban economic and social development. Of building an innovative country strategy, Beijing, Shanghai, Wuhan, Shenzhen, Xi'an and other cities have put forward the goal of building an innovative city. Based on the Path selecting of the innovating-style city of Xi'an low carbon-based view, how does the mainbody play an active and innovative role in the implementation of the main-body innovation strategy? 


\section{The Concept of the Innovating-Style City}

\subsection{The Innovating-Style City}

The so-called innovating-style city is innovation-led strategy for urban development patterns for urban development. Innovative city is different from the traditional extensive mode to the strategy of independent innovation as the core to scientific and technological innovation, institutional innovation, cultural innovation, industrial innovation, living environment, innovation, and various elements of convergence and cooperation, designed to promote urban socio-economic coordination of the innovative features of sustainable development as a whole. This concept includes at least two meanings:

First, the basic idea of innovative city for urban development is to depend on independent innovation. This is to get rid of past urban development on the external environment, the traditional dependence on resources, the initiative to promote urban development to the city's master, and the magic weapon to promote urban development is innovation, relying on the intellectual capital, scientific and technological advances for leveraging traditional resource.

Second, the innovation-oriented city emphasizes on the convergence of co-ordination and sustainable urban development of the innovative elements of the city. Elements of convergence and cooperation not only able to produce work together to promote urban development, but also in the process for these aggregation effect factors themselves have been optimized, and thus able to generate greater cohesion. Construction of innovative city is an endless, ever-merit-based process, because innovation is not the end. It also consistent with the concept of sustainable city development or the life of the city will be halfway to premature death.

\subsection{The Innovating-Style City and Low Carbon}

Carbon element is a necessary component of a variety of organisms; the production of human life is indispensable, "low carbon" is a term quite emphasized in recent years socio-economic areas of the reason why will become the focus derived from the extensive economic development. Extensive urban development patterns in a waste of resources, destruction of the environment, leading to earthquakes, floods droughts, landslides and other natural disasters is difficult to maintain normal production and life of mankind. The reason for advocating the "low-carbon economy", "low-carbon life," "low-carbon city"... because of our economic life and urban development, excessive demand and emissions of carbon, has far exceeded the natural systems the ability to regulate, angered nature.

Construction of innovative city in pursuit of the sustainable development of cities, it must contain the sustainability of cities in harmony with nature and urban organism inside. Urban innovation in order to respect the natural protection of the natural harmony with nature as a starting point and ultimate goal, therefore, the construction of innovative city is bound to low-carbon concept, the low-carbon throughout the urban development has always been.

\subsection{The Classification [1] of Innovating City}

The choice of Innovating urban development model is affected by factors such as economic, institutional, historical impact. There are different categories according to different classification criteria, including marketoriented model of development, government-led model of development in accordance with the government and market forces in the construction of innovative city, as well as a combination of both-a hybrid model of development. Basing on the different content focused in urban innovation activities, it can be divided into the culture of innovating-style city, the service innovative city, and technological innovation-oriented city.

\section{Guiding Ideology of Xi'an Innovative City Construction}

According to the requirements of the development and function of location and resource endowments of the Xi'an City, the construction of Xian's innovative city should aim to the objective of an international metropolis, guide by Deng Xiaoping Theory and the scientific concept of development, furthermore, adhere to the maxim that "Science and technology are primary productive forces" and implement the guidelines of "innovation depending ourselves, crossing over breakthroughs, supporting the development, leading to the future”, carrying indepth out the strategies of science and education and human resource, taking efforts to improve the innovation 
system, foster innovative subjects, train creative talents, promote a culture of innovation, and optimize the environment for innovation. Ultimately, comprehensively enhance the original innovation, integrated innovation and the introduction of digestion and absorption and innovation, and promote technological and industrial upgrading.

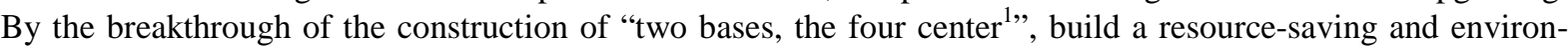
ment-friendly new Xi'an, make it become one of five countries-class innovation-oriented city having complete innovation system, powerful innovation, developed innovative industries, the large pool of innovative talent, and good environmental quality .

\section{Path Selecting of the Innovating-Style City of Xi'an Based on Low-Carbon Economy Perspective}

By analyzing, Xi'an urban development, innovation can be seen walking on two legs: one leg is the road of innovation of cultural tourism, and the other a high-tech road of innovation. The inevitable road of Xi'an city, two paths are innovative, and two paths are in line with the status quo of urban construction, low carbon environmental protection and sustainable development concept.

The "old-city” is the traditional image of the city of Xi'an, while High-tech is a synonym of "Xi'an” (now a mention of Xi'an, no people do not know the high-tech zones.), Cultural Tourism Innovation creates "spirit”, the display of ancient Chinese nation, the birthplace of historical and cultural spirit of the tourists and the people of Xi'an heavy historical influence of strong cultural atmosphere of infection, to produce a feeling of awe and pride; ram of the city construction of high-tech innovation is the "base", boosting the economy development. Without productivity, relations of production are out of the question. Creating "spirit" is also subject to ram the "bases" creating "spirit” and ramming "base” are the fundamental interests of Xi'an, the general public.

The road Chosen of innovation of cultural tourism only, the construction of Xi'an City will immediately lose the foundation, lack of economic resources, even the basic and necessary economic support of cultural tourism operations. Without support of high-tech innovation, the development of cultural tourism will be bleak, like walking into a mix of stalactite cave, there is no lighting tools also appreciating anything. For Xi'an such a profound and long-time culture and rich tourism resources of the city, if only to choose the road of industrialization of high-tech innovation, it will be like a beggar holding the golden bowl. Innovative high-tech city development should continue to sum up, so as to form the culture of innovation, carry forward the spirit of innovation, and remain forever young.

In summary, the innovative city construction of Xi'an must insist on walking on two legs: “cultural tourism innovation for long-term strategic and high-tech innovation to lead the industry innovation”.

\section{Achieve the Innovating-Style City of Xi'an: The Strategy of Main Innovation}

In the process of the innovative urban roads choosing, Must recognize the main body of the city's innovation, including enterprises, universities and research institutions, education and training institutions, and government to implement the strategy of main-body innovation based on enterprise itself' innovation, depending on the strategy of management innovation of the subject and the strategy of talent innovation promoting the main-body sustainable development.

\subsection{Focus on the Implementation of Corporate Innovation Strategy Based on Independent Innovation of Enterprises}

An enterprise, as cells of socio-economic, is the first main body of the innovative city construction, because others have to rely on it to reflect the value, which we can say that enterprise innovation is the most important. How to implement enterprise innovation strategy?

Firstly, choose their own road of innovation combing with their own current situation.

Enterprise innovation has two forms: independent innovation and cooperation innovation, and there are three practical forms: the original innovation, integrated innovation and the introduction of absorption and innovation. In Xi'an, the starting point of enterprises and innovation, require different input of resources vary widely, and

\footnotetext{
${ }^{1}$ Two bases, the four centers: Building world-class integrated energy equipment service base, the national high-tech industries and advanced manufacturing base; to create a regional international financial center and economic center of China's western headquarters, in western China trade and logistics distribution center economic center of Western China Exhibition and the western headquarters of the economic center.
} 
the enterprises must combine the current situation with future strategy while choose their own road of innovation.

At the beginning of the construction of innovative city, Government should encourage and nurture innovative enterprises, enabling them to become the benchmark of innovation. Innovative enterprises should guide by innovative ideas, base on, the innovation system, core technology and brand of intellectual property rights, take comprehensive and sustained innovation means, in order to obtain more profit and achieve continuous development as the goal the new enterprise.

Secondly, strengthen the capability of independent innovation, and strive to foster regional innovation brand-name product on the basis of the analysis of impact of innovation factors.

Independent innovation of enterprises is a comprehensive systems engineering, based on independent technical innovation as the guide, factors impacting independent technological innovation is not only to external macroeconomic factors, but also concerned about the internal micro factors. Recommended that we not only concerned about the impact of independent technological innovation within the enterprise innovation leadership, innovation and coordination, metrics, innovation, resources, process management, strategic coordination and corporate culture of internal factors and competitive pressures, the social environment, the protection of the outcome, the Government's role, total level of integration of industry, academia and research, but also fully stressed concerning about the role of individuals in the business innovation, in particular, the concern can not neglect the internal personal and separated from the enterprise, the freelance like artist [2].

The outline of Xi'an Economic and Social Development Twelfth Five-Year Plan referred to establishment of the technological innovation system with enterprises as the mainstay, perfect financial, fiscal and tax policies for high-tech enterprises innovation, implement the Technology Innovation Program and "gazelle” plan for SMEs, to take comprehensive measures for encouraging enterprises to improve their R \& D investment, and effort to develop the core technology and leading products with independent intellectual property rights within 2015, and specially strive to achieve one hundred enterprises to enter the national, provincial innovation-oriented enterprises ranks. Continue to implement brand strategy, and strive to cultivate more than 10 domestic well-known brands having an influence and competitiveness, nurturing one/two well-known brands of the world-renowned. This target defines the direction of enterprise independent innovation capacity-building, thus we must: encourage enterprises to become the main body of the innovation; to encourage large and medium-sized enterprises to establish R \& D institutions; support to accelerate the development of private technology enterprises and private enterprises technology; strive to foster independent innovation and brand-name products in Xi'an.

Finally, establish the good interaction mechanism of industry academia and research, enterprises as the mainstay of research.

Establish the tripartite cooperation market innovative mechanisms at the core of the government, including enterprises and universities. Governments establish and perfect the technology market and a variety of mechanisms, while universities and enterprises establish an interactive mechanism as a link to the external market transactions. The main source of the project of Universities and research institutions should be driven by market and enterprise rather than government-funded; establish the research information network making full use of modern information technology for mutual communication between industry academia and research, and play the role of scientific and technological intermediary setting up a bridge of communication between the innovation main-bodies. Xi'an, having many colleges and universities, on the one hand, can play their own technology industrial park (such as Xi'an Jiao tong University Science and Technology Industrial Park, Xi'an University of Electronic Science and Technology Industrial Park) as a link with the external market interaction, can also consider to establish a long-term stable relations of R \& D cooperation by the form of exchange "agent” or "observer" between enterprises; the other hand, take the initiative to seek cooperation, "not to have everything, but to do"; in addition, Xi'an municipal government could also consider strengthening the R \& D capabilities of the provincial Xi'an universities and research institutions, encouraging them to market-oriented and training R \& D ability in practice.

\subsection{The Management Innovation Strategy}

Building an innovative city, must leap forward in the management system and method of management innovation strategy implemented by the different innovation players. Including the implementation of the government management innovation and enterprise organization and management innovation strategy, it can be also divided into mechanism innovation, organizational innovation and management methods innovation. 
1) Mechanism innovation

Standing at the government level, the construction of innovative city of institutional innovation that the Government through the development of innovative and incentive effects of the system, the system of norms to implement its social management functions, and achieve a better goal to promote social innovation. At the same time, the system itself is the product of innovative, which is very important, is an innovative government, only innovative government will innovation system, innovation-oriented culture. Present scientific and facing the problems of institutions, mechanisms, policies, regulations, etc., to a large extent depends on the central and local government, whether the spirit of reform to come up with innovative new ideas, while the government from economic activities protagonist into a public service provider, and strive to create high-quality, efficient and honest administrative environment, further improve the comprehensive service system of independent innovation , give full play to the enthusiasm to develop and improve policies and measures to promote independent innovation, and the effective implementation has introduced policy to stimulate all kinds of enterprises, especially SMEs, innovation and vitality.

Standing at the enterprise level, building an innovative system of the city's innovation is the enterprise system adjusts with the change of the external environment and business strategy change. Like as the articles of association, the system of property rights, business organization system and operations system requires constant innovation. Of course, how to encourage innovation and innovation incentives must also be institutionalized, otherwise the business will not last long.

2) Organizational innovation

Organizational innovation includes two levels of meaning: First, the improvement of the organization structure; second, how more effective course of action for the completion of organizational goals and efforts to implement. Such as Xi'an, specially constructed for the creation of the National Health City and Garden City, a so-called "upgrade Office" Organization is established to enhance the image of the city. Overall, the government's organizational structure to maintain a stable continuity of the functions of the government structure is not much change, but change the effectiveness of the management of grass-roots organizations is still very significant, such as streamlining and dynamic. Enterprise organization innovation is to adjust and optimize the structure of the configuration of the elements of management, financial, material, time, information and other resources, to improve the effectiveness of existing management elements Organizational innovation as the new property rights system, the new employment system, the new management mechanism, corporate mergers and strategic restructuring , the company's key personnel to implement the appointment and election system, the adjustment of the corporate officers and shunt more reflects the more win-win cooperation of various functional organs of internal cooperation and coordination among enterprises.

3) Management methods innovation

Innovation itself is a management method, management method innovation have more guidance value than institutional innovation and organizational innovation which are guided by methods, while management method innovation applies to all organizations and individuals. Management method innovation has more response ideology and thinking of systematic change.

\subsection{Talent Innovation Strategy}

Can not do without creative talent for innovative urban construction, and implement innovative human resources strategy, and maximize their creative potential of the innovative talents. According to statistics, to the end of 2009, there are the total human resources of 55.3 million, "five Districts, one harbor and two bases" as the representative of talent highland embryo [3], party and government personnel to 4.1 million people, 11.4 million business management personnel, 12.8 million professional and technical personnel, 16.5 million high-skilled personnel, 9.6 million rural practical personnel, 0.9 million of the social work personnel. All of personnel under the age of 45 are up to 31 million, accounting for $54.1 \%$ of the total. Innovative talent is the most valuable asset of all types of organizations, the most scarce strategic resources, issued by the municipal government of Xi'an and long-term talent development plan that: through great efforts to cultivate high-level creative scientific and technological personnel to give priority to development of economic and social shortage of personnel development needed in key areas, co-ordinate all types of personnel, personnel total average annual growth of 8.4 percent, the years 2015 and 2020 , personnel contribution rates were $33 \%$ and $40 \%$, per million of GDP to the number of people needed were 2.9 and 2.5, 2020, all kinds of talents total up to 134.4 million (see Table 1: key 
Table 1. Key indicators of long-term talent development in Xi'an.

\begin{tabular}{ccccc}
\hline Indicators & Unit & $\mathbf{2 0 0 9}$ & $\mathbf{2 0 1 5}$ & $\mathbf{2 0 2 0}$ \\
\hline $\begin{array}{c}\text { Total human resources } \\
\text { R \& D personnel per 10,000 labor force }\end{array}$ & Million & 55.3 & 89.7 & 134.4 \\
$\begin{array}{c}\text { Man-years/million } \\
\text { wighly skilled personnel accounted for the proportion of skilled }\end{array}$ & $\%$ & 71 & 120 & 169 \\
$\begin{array}{c}\text { Prime working age population proportion of highly educated } \\
\text { Human capital investment to GDP ratio }\end{array}$ & $\%$ & 25.2 & 27.8 & 32 \\
Personnel contribution rate & $\%$ & 11.6 & 17.5 & 25 \\
\hline
\end{tabular}

indicators of Xi'an long-term talent development), the highlands of western talent build a more competitive and innovative vigor and talent resources and strong city.

Implementation of innovative human resources strategy, it is imperative to creating a mass has to have a strong sense of innovation, innovative spirit and ability of innovative entrepreneurs and high-level innovative scientific and technological talents, to build high-level personnel to develop their potential and room to grow, and create good exchanges and cooperation platform; the implementation of innovative human resources strategy must respect labor, respect knowledge, respect talent, and increase the innovative development of human resources efforts to optimize the environment for the growth of innovative talent to create an enabling innovative talent to stand out, fully play a role in the system, mechanism, utilities talent pool, with the practice of nurturing of talent, talent incentive mechanism, the rule of law security personnel to maximize the mobilization of the innovative enthusiasm and initiative of the innovative talents, maximize their potential, to achieve The maximum value of the innovation. To this end, must:

1) Total attracts the best talents.

In the year of 2015, the city's total R \& D personnel will reach 1.9 million and 3 million in 2020 year, the entrepreneurial innovation total of high-level scientific and technological personnel, respectively, 2500 and 3000.

2) Promote new skills, large-scale cultivation of talent.

In the period of "Twelfth Five", Xi' an will carry out innovative talent training base construction, implement 50 innovative team development plan and knowledge updated programs of professional and technical personnel, culture and famous foster program, creative rookie prop plan. Relying on major research projects and major projects, key disciplines and key scientific research base, international academic exchange and cooperation projects, will build a number of high-level innovative scientific and technological personnel training base, focus on the training front-line creative talents, especially young scientists, to play an innovative talent the main role in personnel.

3) Innovate mechanisms, and flexibly use personnel.

4) Promote innovative talent development policy.

Integrate education, science, industry personnel training resources and establish various forms strategic alliances, and support enterprises, colleges and universities jointly cultivate high-level talents and innovative teams. Implement the "personnel + project", the training mode, relying on major projects in the innovative practice to gather and cultivate first-rate talent.

Adhere to the combination of domestic and international, independent development and overseas introduction and utilize the two human resources.

Strengthen personnel radiation driven functionality to support policy. Guanzhong-Tianshui Economic Zone in seven cities and one district integration of human resource development cooperation mechanism to jointly establish a personnel information database, and give full play to the platform capabilities of the talent market in Xi'an

Construction co-ordinate scientific and technological resources reform demonstration base to support policy.

5) Deal with relationships of the innovative talents

First, we must distinguish between the innovative talents with conventional talent. Can not be over and over again with the development of regular personnel policies and measures to develop innovative talents; not in urgent need of shortage of qualified personnel, high-level top-notch talent is equivalent to the innovative talent.

Second, properly handle the leading talent with the official standard. Leading talent is the soul of the innova- 
tive talents is an example of the activities of independent innovation, and incentives can not use the "official position" to stifle the life of the leading talents of innovation, to the extent possible to separate academic and administrative. Colleges and universities to administrative reform is something that is not a very good attempt.

Thirdly, establish the interaction between high-tech industries and innovative talent training. Rely on major research projects, and promote the training of academic leaders and innovative team building, such as the 863 project, the National Torch Plan Project, provincial, municipal key projects, etc.; to encourage and support a variety of R \& D centers, technology centers, innovation service center building, the establishment of a post-doctoral research station, etc.

Finally, deal cautiously with the relationship of the original innovation, the introduction digestion and absorption of innovation and integrated innovation, advocating innovation with independent intellectual property rights.

\section{Conclusion}

In all, main-body is absolutely responded for the every detail of innovating city in all elements. How to enhance the main-body's innovation abilities has became more valuable.

\section{Fund}

This paper is a funded project by Department of Education of P.R.C. in 2011, contract number: 11YJA630100 and by Bureaus of Education of Shaanxi Province in 2014, contract number: $13 B Y 49$.

\section{References}

[1] Gan, D.A. and Huang, Z.Y. (2009) The Choice of Path for Wuhan Innovative Urban Construction. Economic Science Press, Beijing, 18-19.

[2] Liu, J.F. (2010) Researching on the Social Dissociation Individual Innovation by Likert Scale Statistical Analysis. WBM, Internet-Based Business Management Conference American Research Press, 1094-1098.

[3] Cultivate More than One Million Talents, Including 44 Thousands of Part and Government in Xi'an after 10 Years [DB/OL]. http://edu.cnwest.com/content/2010-09/17/content_3502076.htm 